\title{
PERTANGGUNGJAWABAN PIDANA BAGI PELAKU TINDAK PIDANA PENYELUDUPAN MANUSIA
}

\author{
Mhd. Teguh Syuhada Lubis \\ Fakultas Hukum Universitas Muhammadiyah Sumatera Utara \\ Email: teguhsuhada88@gmail.com
}

\begin{abstract}
The developments of information technology and transport is increasing so as to make the boundaries between countries increasingly apparent. Traffic is more easily accessible. More open the traffic between countries in the globalization era also led the increasing of mobility of goods and people between one country to another country. The opening track between countries are not only used for business necessities of life, but also the movement of people from one country to another. The flow of human movement, basically is the goal to find the solution of all the problems that they find in the place of themselves. The movement of human movement is a gap for the occurrence of crime. In the context of transnational crime, human trafficking is a form of transnational organized crime that potentially cause the kinds of implications for other crimes. Human smuggling can be a weak dose of a country's legal system in dealing with covert motivation of the imigiran to make the country as a state intermediary for the crime. Other crimes may arise due to the omission of the practice of human trafficking, such as conventional crimes (fraud, rape, murder, and theft), shipping, human trafficking, money laundering, banking crimes and terrorism.
\end{abstract}

\section{Kata Kunci: Pertanggungjawaban Pidana, Tindak Pidana, Penyeludupan Manusia}

\section{A. Latar Belakang}

Era globalisasi yang ada saat ini membuka peluang untuk terbukanya pasar bebas lintas antar negara. Masing-masing negara memiliki peluang besar untuk saling mengisi kebutuhan di dalam negeri, baik dari segi infrastruktur maupun suprastruktur. Perkembangan teknologi informasi dan transportasi kian meningkat sehingga membuat batas-batas antar negara semakin semu. Jalur lalu lintas pun semakin mudah untuk diakses. Semakin terbuka lebarnya jalan lalu lintas antar negara pada era globalisasi ini menyebabkan meningkatnya pula mobilitas barang dan manusia antar satu negara ke negara lain. Dalam memenuhi kebutuhannya, secara tidak langsung negara membuka lebar pintu masuk dan akses ke dalam 
ruang lingkup batasan negara. Masing-masing individu juga dengan mudah melakukan perjalanan dari satu negara ke negara lain dengan berbagai kepentingan.

Akibat fenomena tersebut, berbagai usaha dilakukan untuk tetap menjaga keamanan dan stabilitas negara, seperti menetapkan peraturan-peraturan tentang keimigrasian, walaupun masih banyak terdapat kelemahan yang dapat dimanfaatkan oleh manusia antarnegara. Awalnya hanya sebagai kegiatan migrasi yang bersifat tradisional atau konvensional, yaitu perpindahan penduduk dari satu negara ke negara lain untuk mencari kehidupan yang lebih baik di negara tujuan, tetapi dengan munculnya negara-negara bangsa yang memiliki kedaulatan atas suatu wilayah mengharuskan arus migrasi memakai pola legal.

Adanya hambatan-hambatan dalam pola migrasi legal, mendorong munculnya keterlibatan kelompok kejahatan lintas negara yang berupaya mengembangkan pola migrasi illegal. Kelompok kejahatan ini memanfaatkan kondisi kelemahan ekonomi, sosial, budaya, dan psikologis masyarakat kelas bawah. Pola migrasi illegal yang berimplikasi munculnya masalah keamanan baru berupa aksi-aksi kejahatan yang melintasi batas negara (transnational crime) yang berkembang menjadi kejahatan lintas negara terorganisasi (transnational organised crime), seperti penyeludupan migran. Indonesia sebagai negara kepulauan terbesar di dunia, rentan terhadap penyeludupan, termasuk penyeludupan migran (Agus Rukanda, http://rukandabanget.blogspot.com).

Arus pergerakan manusia, pada dasarnya perpindahan yang dilakukan selalu bertujuan untuk mencari solusi dari segala permasalahan yang mereka temukan di tempat asalnya. Ketika manusia merasa tidak nyaman dengan kehidupannya karena berbagai masalah, seperti keamanan, ekonomi (tempat tinggal, sandang, pangan), ataupun kondisi politik, ras agama dan ideologi di tempat mereka tinggal sebelumnya, maka naluri untuk mendapatkan tempat yang lebih baik pun akan muncul. Hal ini tidak dapat dipungkiri, karena sejarah mencatat bahwa perpindahan selalu didasari karena ketidaknyaman di tempat sebelumnya, demikian juga yang dilakukan oleh Romawi dan bangsa-bangsa lainnya (Nugrogo, https://nugrohokriminolog.blogspot.co.id). 
Penyeludupan manusia merupakan salah suatu bentuk kejahatan transnasional yang terorganisasi yang potensial menimbulkan berbagai macam implikasi pada kejahatan lain. Penyeludupan manusia dapat menjadi takaran lemahnya sistem hukum suatu negara dalam menangani motivasi terselubung dari para imigran untuk menjadikan negara tersebut sebagai negara perantara untuk kejahatan. Bentuk kejahatan lain dapat saja muncul sering dengan pembiaran praktik penyeludupan manusia seperti; kejahatan-kejahatan konvensional (penipuan, pemerkosaan, pembunuhan dan pencurian), pelayaran, perdagangan orang, pencucian uang, kejahatan perbankan dan tidak menutup kemungkinan adanya kejahatan terorisme (Nugrogo, https://nugrohokriminolog.blogspot.co.id).

Penyeludupan manusia di Indonesia belum dikenal sebagai sebuah kejahatan tetapi lebih dikenal dengan pelanggaran keimigrasian oleh sebagian penegak hukum yang pernah menangani kejahatan ini, karena penanganan kejahatannya yang menggunakan undang-undang keimigrasian. Di sisi lain penyeludupan manusia juga dikenal sebagai kejahatan perdagangan orang, karena mempunyai modus operandi yang mirip, oleh sebab itu penulis tertarik menganalisis pertanggungjawaban pidana dalam hal terjadinya penyeludupan manusia ini.

\section{B. Konsepsi Pertanggungjawaban Pidana dalam Hal Terjadinya Kejahatan}

Tindak pidana berupa kejahatan dipandang dari sudut formil (menurut hukum) adalah suatu perbuatan yang diberi pidana oleh masyarakat (dalam hal ini negara), bila ditinjau lebih dalam sampai pada intinya, maka kejahatan merupakan perbuatan-perbuatan yang bertentangan dengan kesusilaan (Edi Warman, 1994: 6). Bonger sebagaimana dikutip Edi Warman (1994: 7) memberikan penjelasan mengenai pengertian kejahatan yang bertentangan dengan kesusilaan, dimana kesusilaan mengenai tentang sifat dan hakekat dari perbuatan asusila (immoral), terlihat ada 2 (dua) sudut pandangan, yaitu:

1. Pandangan subjektif, yaitu dipandang dari sudut orangnya, adalah perbuatan yang bertentangan dengan kesusilaan. 
2. Pandangan objektif, yaitu jika dipandang dari sudut masyarakat adalah perbuatan yang merugikan masyarakat.

Kejahatan dalam artian kriminologis adalah tiap kelakuan yang bersifat merugikan, yang menimbulkan begitu banyak ketidaktenangan dalam suatu masyarakat tertentu, sehingga masyarakat itu berhak untuk mencelanya dan menyatakan penolakannya atas kelakuan itu dalam bentuk nestapa dengan sengaja diberikan karena kelakuan tersebut (Roeslan Saleh, 1980: 17). Pengertian kejahatan dalam buku terminologi hukum pidana memberikan pengertian kejahatan (misdaad, misdrijf, crime) adalah perbuatan yang dilarang dan diancam dengan pidana berat oleh undang-undang (Andi Hamzah, 2007: 81).

Dalam hal terjadinya kejahatan, maka ada pelaku kejahatan yaitu orang yang telah melakukan kejahatan yang sering pula disebut "penjahat". Penjahat adalah orang yang sering melakukan kejahatan (Andi Hamzah, 2007: 82). Menurut Teori Lambroso tentang born criminal (penjahat yang dilahirkan) dinyatakan bahwa para penjahat adalah suatu bentuk yang lebih rendah dalam kehidupan, lebih mendekati nenek moyang mereka yang mirip kera dalam hal sifat bawaan dan watak dibanding mereka yang bukan penjahat. Mereka dapat dibedakan dari non-kriminal melalui beberapa atavistic stigmata-ciri-ciri fisik dari makhluk pada tahap awal perkembangan, sebelum mereka benar-benar menjadi manusia. Lambroso beralasan bahwa seringkali para penjahat memiliki rahang yang besar dan gigi taring yang kuat, suatu sifat yang pada umumnnya dimiliki mahkluk carnifore yang merobek dan melahap daging mentah. Jangkauan/rentang lengan bawah dari para penjahat sering lebih besar dibanding tinggi mereka, sebagaimana dimiliki kera yang menggunakan tangan mereka untuk menggerakkan tubuh mereka di atas tanah (Topo Santoso dan Eva Achani Zulfa, 2001: 38).

Studi terhadap pelaku kejahatan ini kemudian berkembang ke studi terhadap korban kejahatan yang melahirkan "viktimologi", hal ini dikarenakan pengaruh dari karangan Hans von Henting dan B. Mendelsohn yang berjudul "The Criminal and his Victim" (1949) yang menyatakan bahwa dalam kejahatankejahatan tertentu ditemui adanya peranan korban kejahatan-kejahatan tertentu ditemui, adanya peranan korban yang sangat penting dalam menimbulkan 
kejahatan. Hasil dari studi penyebab kejahatan inilah nantinya yang melahirkan sejumlah teori tentang penyebab kejahatan (Topo Santoso dan Eva Achani Zulfa, 2001: 13).

Ada berbagai faktor penyebab terjadinya suatu tindak kejahatan di kota di bandingkan di pedesaan, sebagai kenyataannya bahwa manusia dalam pergaulan hidupnya sering terdapat penyimpangan terhadap norma-norma, terutama norma hukum. Penyimpangan hukum ini disebut sebagai kejahatan atau pelanggaran, dan kejahatan itu sendiri merupakan masalah sosial yang berada di tengah-tengah masyarakat, dimana si pelaku dan korbannya adalah anggota masyarakat (Kukuh Binanto, http://kukuhbinanto.blogspot.com).

Secara umum ada beberapa faktor yang menyebabkan terjadinya sebuah kejahatan. Pertama, adalah faktor yang berasal atau terdapat dalam diri si pelaku yang maksudnya bahwa yang mempengaruhi seseorang untuk melakukan sebuah kejahatan itu timbul dari dalam diri si pelaku itu sendiri yang didasari oleh faktor keturunan dan kejiwaan (penyakit jiwa). Kedua, adalah faktor yang berasal atau terdapat di luar diri pribadi si pelaku, maksudnya bahwa yang mempengaruhi seseorang untuk melakukan sebuah kejahatan itu timbul dari luar diri si pelaku itu sendiri yang didasari oleh faktor rumah tangga dan lingkungan, tetapi faktor yang paling menentukan dalam hal ini adalah faktor lemahnya iman, jika iman lemah atau iman seseorang tidak ada, maka perbuatan pasti akan terjadi tanpa ada yang dapat mencegahnya (Kukuh Binanto, http://kukuhbinanto.blogspot.com).

Dalam hal terjadinya kejahatan, maka aspek penting yang perlu dilihat adalah terkait dengan tanggung jawab seseorang akibat adanya perbuatan itu. Pertanggungjawaban pidana dalam Bahasa Belanda disebut dengan istilah "toerekenbaarheid" atau dalam Bahasa Inggris disebut dengan istilah "criminal responsibility". Pertanggungjawaban pidana dimaksudkan untuk menentukan apakah seseorang terdakwa dipertanggungjawabkan atas suatu tindak pidana yang terjadi atau tidak, apabila ternyata tindakannya bersifat melawan hukum dan terdakwa mampu bertanggungjawab, maka dapat dipidana.

Berbicara tentang pertanggungjawaban, maka tidak dapat dilepaskan dengan tindak pidana, walaupun dalam pengertian tindak pidana tidak termasuk 
masalah pertanggungjawaban pidana. Tindak pidana hanya menunjuk kepada dilarangnya suatu perbuatan. Dasar adanya tindak pidana adalah asas legalitas, sedangkan dasar dapat dipidananya pembuat adalah asas kesalahan, berarti bahwa pembuat tindak pidana hanya akan mempertanggungjawabkan suatu perbuatan pidana jika ia mempunyai kesalahan dalam melakukan tindak pidana tersebut (Nugrogo, https://nugrohokriminolog.blogspot.co.id)

Menurut Moeljatno dalam pidato Dies Natalies sebagai mana dikutip Nugrogo (https://nugrohokriminolog.blogspot.co.id), dikatakan bahwa antara perbuatan pidana dan pertanggungjawaban dalam hukum pidana, ada hubungan erat seperti halnya dengan perbuatan dan orang yang melakukan perbuatan. Kemampuan bertanggungjawab menurut Roeslan Saleh (1980: 80) adalah mampu untuk menginsyafi sifat melawan hukumnya perbuatan dan sesuai dengan keinsyafan itu mampu untuk menentukan kehendaknya.

\section{Tindak Pidana Penyeludupan Manusia}

Penyeludupan manusia (smuggling), menurut definisi Pasal 3 Protokol PBB Tahun 2000 tentang Penyeludupan Manusia adalah mencari untuk mendapat, langsung maupun tidak langsung, keuntungan finansial atau materi lainnya, dari masuknya seseorang secara illegal ke suatu bagian negara, dimana orang tersebut bukanlah warga negara atau memiliki izin tinggal. Masuk secara illegal berarti melintasi batas negara tanpa mematuhi peraturan/perijinan yang diperlukan untuk memasuki wilayah suatu negara secara legal.

Penyeludupan manusia unsur yang hampir sama dengan perdagangan orang, yaitu ada unsur proses, cara dan tujuan. Unsur proses adalah aktivitas pemindahan seorang (sama seperti dalam perdagangan orang). Unsur cara adalah tidak ada unsur penyelewengan persetujuan kehendak pribadi, maupun dengan penggunaan kekerasan, umumnya calon migran mencari dan memulai kontak dengan penyelundup sendiri dengan menyadari tujuannya, yaitu untuk melintasi batas suatu negara secara illegal, sedangkan unsur tujuan, yaitu selalu ada nilai mendapatkan keuntungan berupa finansial dan pelaksanaannya untuk tujuan 
melintasi perbatasan negara yang dilakukan secara illegal (Nur Kusuma Wardani, http://journal.unair.ac.id).

Perbedaan mendasar antara perdagangan orang dengan penyeludupan manusia, adalah dari sifat dan kualitas persetujuannya, dalam perdagangan orang persetujuannya diperoleh karena kekerasan, paksaan, penipuan, sedangkan penyeludupan manusia selalu ada persetujuan untuk pemindahan. Dari kepentingan, dimana perdagangan orang tujuannya selalu eksploitas, sedangkan penyeludupan manusa tunjuannya pemindahan orang secara illegal. Dilihat dari sifat hubungan antara individu dengan fasilitator/pihak yang mengeksploitasi, dimana perdagangan orang antara (korban dan traffiker) terjadi hubungan jangka panjang, berkesinambungan, hingga korban berada di negara tujuan hubungan ini masih berlangsung, sedangkan penyeludupan manusia antara (pembeli dan pemasok) hubungan jangka pendek dan putus setelah kegiatan pemindahan ke suatu negara tercapai Nur Kusuma Wardani, http://journal.unair.ac.id).

Selain persamaan, terdapat pula perbedaan antara keduanya, bahwa penyulundupan manusia (human smuggling) lebih banyak menekankan unsur illegalitas dan perpindahan seseorang lintas perbatasan, sedangkan dalam kasus perdagangan yang terpenting bukan persoalan sah atau tidaknya perpindahan itu secara geografis, tetapi yang menjadi fokus perhatian adalah adanya unsur eksploitasi, pemanfaatan, dan perlakuan salah kepada korban. Perdagangan orang selalu menggunakan kekerasan dan intimidasi, guna mempertahankan korban tetap berada dalam situasi tereksploitasi, sedangkan untuk penyeludupan manusia tidak selalu menggunakan kekerasan dan intimidasi. Dari segi otonomi dan kebebasan, untuk perdagangan orang dimana korban selalu dalam posisi lemah, sedangkan untuk penyeludupan manusia korban biasanya tidak terlalu lemah kecuali jika dibutuhkan agar pemindahan berhasil. Dari aspek geografis, perdagangan orang terjadi secara internal dan lintas batas negara, sedangkan penyeludupan manusia terjadi secara lintas batas negara. Dari segi dokumen, perdagangan orang bisa legal maupun illegal, sedangkan penyeludupan manusa biasanya selalu illegal, dan yang terakhir dari segi kejahatan, dimana untuk perdagangan orang selalu terjadi pelanggaran hak asasi manusia dan sifat dari 
kejahatannya dilakukan terhadap individu, sedangkan untuk penyeludupan manusia bersifat kejahatan terhadap negara (Bagong Suyanto, 2006: 13).

Penyeludupan manusia adalah kejahatan, karena penyeludupan manusia secara jelas melanggar ketentuan-ketentuan resmi dari negara-negara yang bersangkutan. Telah diakui bahwa penyeludupan manusia merupakan suatu tindakan melanggar hak asasi manusia dan bentuk perbudakan kontemporer. Para imigran diperlakukan dengan tidak baik sangat sering kondisi perjalanan yang tidak manusiawi ditumpuk dalam angkutan (umumnya perahu) yang penuh dan sesak, dan bahkan sering terjadi kecelakaan yang fatal. Setibanya di tempat tujuan, status illegal mereka menyebabkan mereka terpaksa menjadi budak para penyelundup yang memaksa bekerja selama bertahun-tahun di pasar tenaga kerja illegal. Para imigran secara tidak langsung dieksploitasi oleh pihak tertentu demi keuntungan materil (Mansur Zikri, http://manshurzikri.wordpress.com).

Penyeludupan manusia menjadi lahan bisnis tersendiri yang sangat menguntungkan. Diperkirakan setiap tahunnya dapat menghasilkan keuntungan sebesar lima hingga sepuluh juta dolar. Berdasarkan perkiraan tersebut, setidaknya satu juta imigran harus membayar rata-rata sebesar lima hingga sepuluh ribu dolar secara paksa ketika melintasi perbatasan antar negara. Organisasi Internasional untuk Migrasi (IOM) mencatat bahwa penyeludupan manusia, yang merupakan "sisi gelap" dari globalisasi, adalah sebuah bisnis besar yang kian tumbuh dan berkembang. Selain itu, penyeludupan manusia juga menimbulkan masalah tersendiri bagi negara tempat mereka meminta suaka. Hal ini juga melanda negara Indonesia (Mansur Zikri, http://manshurzikri.wordpress.com).

Praktik penyeludupan orang atau people smuggling telah meningkat dalam beberapa dekade terakhir dan pada saat ini, laporan signifikan mengenai jumlah imigrasi tidak resmi terus meningkat di berbagai negara, termasuk di Indonesia, yang semula sebagai negara transit saat sekarang ini menjadi negara tujuan. People smuggling umumnya dapat terjadi dengan persetujuan dari orang atau kelompok yang berkeinginan untuk diselundupkan, dan alasan yang paling umum dari mereka adalah peluang untuk mendapatkan pekerjaan atau memperbaiki status ekonomi, harapan untuk mendapatkan penghidupan yang lebih baik bagi 
diri sendiri atau keluarga, dan juga untuk pergi menghindari konflik yang terjadi di negara asal (Mansur Zikri, http://manshurzikri.wordpress.com).

People smuggling dan imigran gelap merupakan suatu tindakan pidana yang saling kait mengait. Kegiatan tersebut dapat terjadi jika salah satunya dapat direalisasikan, dalam artian bahwa imigran gelap akan berhasil dengan adanya persekongkolan dari agen-agen penyeludup, dan menyeludup orang mengakibatkan semakin meningkatnya jumlah imigran gelap. Penyeludupan manusia (people smuggling) dapat diartikan mencari untuk mendapat, langsung maupun tidak langsung, keuntungan finansial atau materi lainnya, dari masuknya seseorang secara illegal ke suatu bagian negara dimana orang tersebut bukanlah warga negara atau memiliki izin tinggal. Masuk secara illegal ke suatu negara secara legal (Sam Fernando, http://hukum.ub.ac.id).

Berdasarkan pendapat yang diuraikan di atas, maka dapat dikatakan bahwa penyeludupan manusia pada umumnya dipahami sebagai pengadaan atau pengangkutan manusia untuk mendapatkan keuntungan untuk masuk secara illegal ke dalam sebuah negara, tetapi menyediakan fasilitas untuk masuk atau melintasi sebuah negara secara illegal, secara tersendiri, bukanlah perdagangan manusia, walaupun seringkali dilaksanakan dalam keadaan yang berbahaya, bahkan mempertaruhkan keselamatan jiwa.

Penyeludupan seringkali melibatkan para migran yang telah setuju dengan kegiatan tersebut, sedangkan perdagangan manusia, dapat tanpa persetujuan mereka atau kalaupun korban pada awalnya sudah memberi persetujuan, persetujuan mereka telah ditiadakan karena pemaksaan, penipuan, atau tidakan kejam dari pada pelaku perdagangan.

Korban perdagangan manusia seringkali tidak menyadari bahwa mereka akan dipaksa melakukan prostitusi atau mengalami situasi kerja paksa yang bersifat eksploitasi. Oleh sebab itu, penyeludupan manusia dapat menjadi perdagangan illegal. Komponen kunci yang membedakan perdagangan dengan penyeludupan adalah unsur kecurangan, penipuan, atau pemaksaan. Tidak seperti penyeludupan, perdagangan manusia dapat terjadi baik korban dipindahkan di dalam negeri atau ke luar negeri. 


\section{Pertanggungjawaban Pidana Penyeludupan Manusia}

Perbuatan tindak pidana penyeludupan manusia merupakan suatu tindak pidana di bidang keimigrasian. Istilah imigrasi berasal dari Bahasa Belanda, yaitu "immigratie", yang berasal dari Bahasa Latin, yaitu "immigratio", dengan kata kerjanya, "immigreren", yang di dalam Bahasa Latinnya disebut "immigrare" dan selanjutnya lazim disebut menjadi "immigratie". Dalam Bahasa Inggris disebut "immigration", yang terdiri dari 2 (dua) kata "in" artinya "dalam" dan "migrasi" artinya "pindah, datang, masuk atau boyong" (Sihar Sihombing, 2009: 2).

Pengertian imigrasi adalah; pindah, datang, atau pemboyongan orangorang masuk ke suatu negara. Dalam Bahasa Inggris dirumuskan: "immigration is the entrance ito an alien country of persons intending to take part in the life of that country and to make it their more or less permanent residence". Pernyataan ini mengandung arti bahwa pemasukan ke suatu negara asing dari orang-orang yang berniat untuk menumpang hidup atau mencari nafkah. Sedikit atau banyak menjadikan negara itu untuk tempat mereka berdiam atau menetap (Sihar Sihombing, 2009: 2).

Menurut Pasal 1 angka 1 Undang-undang Nomor 6 Tahun 2011 tentang Keimigirasian, disebutkan bahwa keimigrasian adalah hal ihwal lalu lintas orang yang masuk atau keluar Wilayah Indonesia, serta pengawasannya dalam rangka menjaga tegaknya kedaulatan negara. Menurut Kamus Besar Bahasa Indonesia "keimigrasian adalah perihal yang bertalian dengan imigrasi; seluk-beluk imigrasi: ia dikenakan tindakan berupa deportasi dan namanya dicantumkan dalam daftar penangkalan".

Keimigrasian dapat dirumuskan sebagai hal ihwal lalu lintas orang yang masuk atau ke luar wilayah republik Indonesia dan pengawasan terhadap orang asing di wilayah Negara Republik Indonesia, dimana setiap orang dapat keluar wilayah Indonesia setelah mendapatkan tanda bertolak, dan yang dimaksud dengan tanda bertolak adalah tanda tertentu yang diterakan oleh pejabat imigrasi di tempat pemeriksaan imigrasi dalam surat perjalanan setiap orang yang akan meninggalkan wilayah Indonesia. Sebaliknya, setiap orang asing dapat masuk ke wilayah Indonesia setelah mendapat izin masuk. Izin masuk yang dimaksudkan di 
sini adalah izin yang diterakan pada Visa atau Surat Perjalanan orang asing untuk memasuki wilayah Indonesia yang diberikan oleh pejabat imigrasi di tempat pemeriksaan imigrasi (Koerniatmanto Soetoprawiro, 1994: 74).

Dalam peraturan perundang-undangan diatur kewajiban setiap orang, baik untuk orang Indonesia maupun untuk orang asing yang mau masuk wilayah Indonesia (Sihar Sihombing, 2009: 17), yaitu:

1. untuk Warga Negara Indonesia yang akan masuk ke wilayah Negara Republik Indonesia, maka mereka diwajibkan untuk:

a. memiliki surat perjalanan yang sah dan masih berlaku;

b. memiliki lembar $\mathrm{E} / \mathrm{D}$, dan

c. pemeriksaan keimigrasian di tempat pemeriksaan imigrasi

2. untuk Warga Negara Asing yang mau masuk ke wilayah Negara Republik Indonesia, maka mereka diwajibkan untuk:

a. memiliki surat perjalanan yang sah dan masih berlaku;

b. memiliki visa yang masih berlaku, kecuali orang yang tidak diwajibkan memiliki visa, dan

c. memiliki lembar E/D, kecuali bagi pemegang kartu elektronik.

Selain itu ada hal yang perlu dilakukan terhadap orang asing, yaitu pemeriksaan: (1) tiket untuk kembali atau untuk meneruskan perjalanan ke negara lain; (2) keterangan mengenai jaminan hidup selama berada di Indonesia; atau (3) keterangan kesehatan bagi negara yang terkena wabah. Berdasarkan hasil pemeriksaan tersebut, petugas keimigrasian di tempat pemeriksaan imigrasi dapat memberikan keputusan: (1) menolak pemberian ijin masuk karena dianggap tidak memenuhi ketentuan-ketentuan tersebut di atas; atau (2) memberikan ijin masuk karena telah memenuhi ketentuan-ketentuan sebagaimana yang telah disebutkan diatas atau untuk yang telah memiliki ijin masuk kembali, masih berlaku ijinnya. Penolakan atau tidak pemberian izin keimigrasian, apabila orang asing:

1. Tidak memiliki Surat Perjalanan yang sah atau tidak berlaku;

2. Tidak memiliki visa, kecuali orang yang tidak diwajibkan memiliki visa sebagaimana diatur dalam Pasal 7 ayat (1) huruf a Undang-undang Nomor 9 
Tahun 1992, yakni orang asing warga negara dari negara yang berdasarkan Keputusan Presiden tidak diwajibkan memiliki Visa $\mathrm{E}$

3. Menderita gangguan jiwa atau penyakit menular yang membahayakan kesehatan umum.

4. Tidak memiliki izin masuk kembali atau tidak mempunyai izin masuk ke negara lain

5. Memberikan keterangan yang tidak benar dalam memperoleh Surat Perjalanan dan/atau visa.

Orang-orang yang tidak dapat izin keimigrasian ini, untuk tetap masuk dalam wilayah Negara Indonesia, lazimnya menempuh cara-cara illegal melalui penyeludupan, yang dapat dikategorikan sebagai tindak pidana keimigrasian.

Mengenai bentuk penyeludupan manusia dalam tindak pidana keimigrasian menurut Noldy Mohede (2011: 41), antara lain:

1. Orang asing yang dengan sengaja membuat palsu atau memalsukan visa atau izin keimigrasian.

2. Orang asing yang dengan sengaja menggunakan visa atau izin keimigrasian palsu atau yang dipalsukan untuk masuk atau berada di wilayah indonesia.

3. Orang asing yang dengan sengaja menyalahgunakan atau melakukan kegiatan yang tidak sesuai dengan maksud pemberian izin keimigrasian yang diberikan kepadanya

4. Setiap orang yang dengan sengaja:

a. menggunakan Surat Perjalanan Republik Indonesia sedangkan ia mengetahui atau sepatutnya menduga bahwa Surat Perjalanan itu palsu atau dipalsukan.

b. menggunakan Surat Perjalanan orang lain atau Surat Perjalanan Republik Indonesia yang sudah dicabut atau dinyatakan batal, atau menyerahkan kepada orang lain Surat Perjalanan Republik Indonesia yang diberikan kepadanya, dengan maksud digunakan secara tidak berhak.

c. memberikan data yang tidak sah atau keterangan yang tidak benar untuk memperoleh Surat Perjalanan Republik Indonesia bagi dirinya sendiri atau orang lain.

d. memiliki atau menggunakan secara melawan hukum 2 (dua) atau lebih Surat Perjalanan Republik Indonesia yang semuanya berlaku;

5. Setiap orang yang dengan sengaja dan melawan hukum mencetak, mempunyai, menyimpan blanko Surat Perjalanan Republik Indonesia atau blanko dokumen keimigrasian.

6. Setiap orang yang dengan sengaja dan melawan hukum membuat, mempunyai atau menyimpan cap yang dipergunakan untuk mensahkan Surat Perjalanan Republik Indonesia atau dokumen keimigrasian. 
7. Setiap orang yang dengan sengaja dan melawan hukum untuk kepentingan diri sendiri atau orang lain merusak, menghilangkan atau mengubah baik sebagian maupun seluruhnya keterangan atau cap yang terdapat dalam Surat Perjalanan Republik Indonesia.

8. Setiap orang yang dengan sengaja dan melawan hukum untuk kepentingan diri sendiri atau orang lain mempunyai, menyimpan, mengubah atau menggunakan data keimigrasian baik secara manual maupun elektronik.

9. Pejabat yang dengan sengaja dan melawan hukum memberikan atau memperpanjang berlakunya Surat Perjalanan Republik Indonesia atau dokumen keimigrasian kepada seseorang yang diketahuinya tidak berhak.

Penyeludupan manusia ada tiga, yaitu: benar-benar diseludup, menyeludup sendiri dan penyeludupan secara sukarela (wikipedia, http://wikipedia.org).

1. Benar-benar diseludup, maksudnya bahwa seorang atau sekelompok manusia diangkut dari suatu negara ke negara lain dengan cara paksaan. Hal ini dilakukan untuk kepentingan berbagai pihak yang tidak bertanggungjawab atas apa yang akan terjadi pada orang yang diseludupkan tersebut, kebanyakan mereka yang diseludupkan itu adalah wanita dan anak-anak. Wanita-wanita dan anak-anak yang diseludupkan tersebut akan dijual kepada penampung yang berada di negara tersebut. Banyak dari mereka dipekerjakan bukan menjadi kehendak mereka sendiri, biasanya wanita akan menjadi buruh di pabrik, pekerja rumah tangga dan pekerja seks komersial yang terorganisir, sedangkan anak-anak lebih banyak menjadi pengemis di jalanan atau menjadi pekerja paksa.

2. Menyelundup sendiri, maksudnya bahw memasuki negara lain tanpa dokumen yang sah melalui jalur illegal menuju pintu masuk tidak resmi dari negara tersebut, tindakan tersebut dilakukan tanpa adanya paksaan orang lain dan melakukannya sendiri. Kebanyakan para pelaku penyeludupan ini untuk mencari pekerjaan kasar ataupun hanya jalan-jalan semata, agar terhindar dari biaya yang besar dan persyaratan yang rumit.

3. Penyeludupan secara sukarela, maksudnya bahwa seorang atau sekelompok orang yang ingin diseludupkan ke negara lain tanpa ada paksaan dari pihak manapun. Mereka yang melakukan hal ini lebih kepada mengirit biaya untuk bekerja di negara orang lain, dikarenakan administrasi yang dilakukan tersebut tidaklah serumit jika mereka melakukan secara legal. 
Penyeludupan manusia sebagai kejahatan terorganisir telah dibahas di dalam United Nation Convention against Transnational Organized Crime atau Konvensi PBB melawan Kejahatan Transnasional Terorganisir. Indonesia telah menyetujui hasil konvensi tersebut dan penandatanganan pada tanggal 12 Desember 2000 (Ken Lazuardhi Syarnubi, 2014: 18). Hasil dari konvensi PBB melawan kejahatan transnasional terorganisir akhirnya disahkan melalui Undangundang Nomor 5 Tahun 2009, guna untuk memperkuat kerja sama internasional dan ditingkatkan agar dapat mencegah dan memberantas tindak pidana transnasional yang terorganisasi. Dengan berlakunya Undang-undang Nomor 6 Tahun 2011 dan Undang-undang Nomor 5 tahun 2009, diharapkan Indonesia dapat melakukan penegakan hukum terhadap para pelaku penyeludupan manusia yang dapat mengancam kehidupan sosial masyarakat di Indonesia, yang memberi legalitas untuk memberikan sanksi atau hukuman bagi pelaku penyeludupan manusia.

Sanksi atau hukuman adalah akibat hukum bagi pelanggar ketentuan undang-undang, ada sanksi administrasi, ada sanksi perdata dan sanksi pidana. (Andi Hamzah, 2007: 138). Mengenai sanksi atau hukuman yang diberikan kepada pelaku tindak pidana dilihat dari sistem pemidaaan, dimana sistem pemidanaan adalah menetapkan suatu sanksi. Keberadaan sistem pemidanaan akan memberikan arah dan pertimbangan mengenai apa yang seharusnya dijadikan sanksi dalam suatu tindak pidana untuk menegakkan berlakunya normanorma. Di sisi lain, pemidanaan itu sendiri merupakan proses paling kompleks dalam sistem peradilan, karena melibatkan banyak orang dan institusi yang berbeda.

Pemidanaan dapat diartikan sebagai tahap penetapan sanksi dan juga pemberian sanksi dalam hukum pidana. Hal ini dapat disimak dari pendapat Sudarto yang menyatakan bahwa pemberian pidana in abstracto adalah menetapkan stelsel sanksi hukum pidana yang menyangkut pembentukan undang-undang, sedangkan pemberian pidana concerto menyangkut berbagai badan yang kesemuanya mendukung dan melaksanakan stelsel sanksi hukum pidana itu. Sanksi dalam hukum pidana adalah semua reaksi terhadap pelanggaran hukum 
yang ditentukan undang-undang dimulai dari penahanan tersangka dan penuntutan terdakwa sampai pada penjatuhan vonis oleh hakim.

Hukuman atau sanksi yang dianut hukum pidana membedakan hukum pidana dengan bagian hukum yang lain. Hukuman dalam hukum pidana ditujukan untuk memelihara keamanan dan pergaulan hidup yang teratur, yang menjadi perbedaan para pakar adalah dasar diadakannya hukuman tersebut, yang akhirnya menimbulkan 3 (tiga) teori (Leden Marpaung, 2008: 105-107), yakni:

1. Teori absolut (teori pembalasan)

Menurut teori ini, dasar hukuman harus dicari dari kejahatan itu sendiri, karena kejahatan itu telah menimbulkan penderitaan kepada orang lain, sebagai imbalannya si pelaku harus diberi penderitaan. Beberapa pakar sebagai penganjur teori ini di antaranya Immanuel Kant yang mengatakan "fiat justitia ruat coelum" yang artinya "walaupun besok dunia akan kiamat, tetapi penjahat terakhir harus menjalani pidananya”. Kant mendasarkan teorinya berdasarkan prinsip moral dan etika. Menurut Thomas Aquinas pembalasan sesuai dengan ajaran Tuhan, karena itu harus dilakukan pembalasan kepada penjahat.

2. Teori relative (teori maksud dan tujuan)

Berdasarkan teori ini hukuman dijatuhkan untuk melaksanakan maksud atau tujuan dari hukuman itu, yakni memperbaiki ketidakpuasan masyarakat sebagai akibat kejahatan itu. Tujuan hukuman harus dipandang secara ideal dan selain itu tujuan hukuman adalah untuk mencegah (prevensi) kejahatan.

3. Teori verenigingstheorie (teori gabungan)

Teori gabungan adalah gabungan dari teori di atas, gabungan kedua teori ini mengajarkan bahwa penjatuhan hukuman adalah untuk mempertahankan tata tertib hukum dalam masyarakat dan memperbaiki pribadi si penjahat.

Mengenai sanksi atau hukuman dalam hukum pidana yang dijatuhkan utamanya mengacu pada Kitab Undang-undang Hukum Pidana (KUHP), tetapi untuk hukum pidana khusus ternyata ada perluasan atau penambahan bentuk atau jenis pidana tambahan di luar yang termaktub di dalam KUHP. Dalam pengusutan terhadap kasus penyeludupan manusia, pihak penyidik kepolisian melihat ada ketentuan dalam KUHP yang dilanggar oleh pelaku penyeludupan manusia yakni 
Pasal 263 KUHP, mengenai pemalsuan surat-surat. Ayat (1) menentukan bahwa barang siapa membuat secara tidak benar atau memalsukan surat yang dapat menimbulkan sesuatu hak, perikatan atau pembebasan hutang, atau yang diperuntukkan sebagai bukti dari sesuatu hal, dengan maksud untuk memakai atau menyuruh orang lain memakai surat tersebut seolah-olah isinya benar dan tidak dipalsu, diancam, jika pemakaian surat tersebut dapat menimbulkan kerugian karena pemalsuan surat, dengan pidana penjara paling lama enam tahun. Ayat (2) menentukan bahwa diancam dengan pidana yang sama, barang siapa dengan sengaja memakai surat yang isinya tidak benar atau yang dipalsukan, seolah-olah benar dan tidak dipalsu, apabila pemakaian surat itu dapat menimbulkan kerugian.

Ketentuan dalam Pasal 263 KUHP ini lebih kepada pelaku yang memalsukan surat atau dokumen perjalanan orang asing atau warga negara Indonesia yang masuk atau ke luar dari wilayah Indonesia demi menghindari prosedur yang ketat. Seiring dengan perkembangan zaman, ternyata KUHP tidak mampu menanggulangi masalah kedatangan imigran gelap yang diakomodasi oleh penyelundup khususnya (Eranovita Kalalo Paembonan, 2014: 7).

Berdasarkan penjelasan Pasal 47 UU No. 9 Tahun 1992, dikatakan bahwa tindak pidana imigrasi termasuk tindak pidana umum, tetapi menurut Mulyatmo dan Sathochid, dikatakan bahwa tindak pidana umum adalah sebagaimana diatur di dalam Buku II dan Buku III KUH, dengan demikian, di luar ketentuan tersebut dikategorikan sebagai tindak pidana khusus. Mengingat Undang-undang Nomor 6 Tahun 2011 mengatur sanksi tersendiri di luar ketentuan Buku II dan Buku III KUHP, maka sesuai dengan pendapat kedua pakar di atas, tindak pidana imigrasi dikategorikan sebagai tindak pidana khusus, dan berlaku ketentuan lex spesialis derogat lex generalis.

Tindak pidana penyeludupan manusia merupakan suatu kejahatan dimana setiap tindak pidana atau kejahatan akan diberi sanksi. Sanksi dalam hukum pidana adalah semua reaksi terhadap pelanggaran hukum yang ditentukan undangundang dimulai dari penahanan tersangka dan penuntutan terdakwa sampai pada penjatuhan vonis oleh hakim, dan dalam Pasal 10 KUHP telah ditetapkan jenisjenis pidana, yaitu pidana pokok dan pidana tambahan. Pidana pokok terdiri dari 
empat jenis pidana, dan pidana tambahan terdiri atas tiga jenis pidana. Jenis pidana menurut Pasal 10 KUHP adalah:

1. Pidana pokok yang meliputi:

a. Pidana mati

Pidana mati sebagai mana yang ditentukan dalam Pasal 11 KUHP yaitu pidana mati dijalankan oleh algojo di tempat gantungan pada leher terpidana, kemudian menjatuhkan papan tempat terpidana berdiri. Pidana mati ini dilaksanakan atau dieksekusi akan setelah mendapatkan Fiat Eksekusi dari Presiden (Kepala Negara).

b. Pidana penjara

Pidana penjara adalah pidana yang paling banyak dimuat di dalam KUHP dan ketentuan pidana lainnya. Pidana penjara adalah pidana berupa pembatasan kemerdekaan bagi pelaku tindak pidana ke dalam suatu rumah penjara. Hal yang diharapkan bagi si terpidana untuk merenungkan dan menyadari segala kesalahan yang telah diperbuatnya. Istilah penjara berasal dari kata "penjera" atau dalam bahasa jawa "penjero". Terdapat 3 (tiga) sistem pemenjaraan, yaitu:

1) Sistem pensylvania/cellulaire sistem

Sistem dimana terpidana dimasukkan dalam sel-sel tersendiri, dan sama sekali tidak dizinkan menerima tamu, baik tamu dari luar maupun sesame narapidana.

2) Sistem auburn

Sistem ini disebut juga sistem silent karena pada malam hari terpidana dimasukkan ke dalam sel sendiri, tetapi pada siang hari diwajibkan bekerja sama dengan narapidana lain, tetapi dilarang berbicara antar sesama narapidana atau kepada orang lain.

3) Sistem English/Progresif

Sistem ini dilakukan secara bertahap, tahap pertama selama tiga bulan, terpidana menggunakan celluler sistem, setelah ada kemajuan si terpidana diperbolehkan menerima tamu, tahap selanjutnya ia boleh menjalani pidananya di luar tembok penjara. 
c. Pidana kurungan

Hukuman kurungan lebih ringan dari hukuman penjara. Lebih ringan antara lain, dalam hal melakukan pekerjaan yang diwajibkan dan kebolehan membawa peralatan yang dibutuhkan terhukum sehari-hari, misal tempat tidur, selimut dan lain-lain.

Hukuman kurungan dapat dilaksanakan dengan batasan paling sedikit satu hari dan paling lama satu tahun. Lamanya hukuman kurungan ini ditentukan dalam Pasal 18 KUHP yang menentukan sebagai berikut:

"Paling sedikit satu hari dan paling lama setahun, dan jika ada pemberatan karena gabungan atau pengulangan atau karena ketentuan Pasal 52 dapat ditambah menjadi satu tahun empat bulan. Pidana kurungan sekali-kali tidak boleh lebih dari satu tahun empat bulan”.

d. Pidana denda

Pidana denda adalah hukuman berupa kewajiban seseorang untuk mengembalikan keseimbangan hukum dan menebus dosanya dengan pembayaran sejumlah uang.

2. Pidana tambahan

Pidana tambahan hanya dapat dijatuhkan bersama-sama dengan hukuman pokok. Penjatuhan hukuman tambahan itu biasanya bersifat fakultatif, dan hakim tidak diharuskan menjatuhkan hukuman tambahan, ada beberapa pidana tambahan

a. Pencabutan beberapa hak-hak tertentu

b. Perampasan barang-barang tertentu

c. Pengumuman putusan hakim.

\section{E. Penutup}

Kejahatan penyeludupan manusia dilihat sebagai perbuatan memindahkan orang dari suatu tempat ke tempat lain tanpa berkas atau dokumen lengkap untuk memasuki suatu wilayah hukum. Pertanggungjawaban pidana bagi pelaku tindak pidana penyeludupan manusia yang terdapat dalam ketentuan Pasal 120 ayat (1) UU No. 6 Tahun 2011. 


\section{DAFTAR PUSTAKA}

\section{Buku:}

Andi Hamzah. 2007. Terminologi Hukum Pidana. Jakarta: Sinar Grafika.

Edi Warman. 1994. Selayang Pandang Tentang Kriminologi. Medan: USU Press.

Koerniatmanto Soetoprawiro. 1994. Tindak Pidana Keimigrasian. Jakarta: Gramedia Pustaka Utama.

Marpaung, Leden. 2008. Asas, Teori, Praktik Hukum Pidana. Jakarta: Sinar Grafika

Roeslan Saleh. 1980. Perbuatan Pidana dan Pertanggungjawaban Pidana. Jakarta: Aksara Baru.

Sihombing, Sihar. 2009. Hukum Imigrasi. Bandung: Nuansa Aulia.

Topo Santoso dan Eva Achani Zulfa. 2001. Kriminologi. Jakarta: RajaGrafindo Persada.

\section{Jurnal/Majalah/Karya Ilmiah:}

Bagong Suyanto. 2006. "Kebijakan dan Program Penanggulangan Women and Child Trafficking belajar dari kasus Propinsi Jawa Timur". Majalah Pledoi. Vol. 1.

Eranovita Kalalo Paembonan, 2014. "Pertanggungjawaban Pidana terhadap Tindak Pidana Penyeludupan Orang (People Smuggling)". Lex Crimen, Vol. 3. No. 4. Fakultas Hukum Unsrat. Manado.

Ken Lazuardhi Syarnubi. 2014 "Penyeludupan Manusia oleh Sindikat Internasional di Jakarta". Karya Ilmiah. Depok: Fakultas Hukum Universitas Indonesia.

Noldy Mohede. 2011 "Sanksi Pidana terhadap Pelaku Tindak Pidana Keimigrasian”, Jurnal Hukum Unsrat. Vol. XIX. No. 4. Juli-September.

\section{Peraturan Perundang-undangan:}

Republik Indonesia, Undang-undang Nomor 1 Tahun 1946 tentang Peraturan Hukum Pidana.

Republik Indonesia, Undang-undang Nomor 5 Tahun 2009 tentang Pengesahan United Nations Convention Against Transnational Organized Crime (Konvensi Perserikatan Bangsa Bangsa Menentang Tindak Pidana Transnasional yang Terorganisasi). 
Republik Indonesia, Undang-undang Nomor 6 Tahun 2011 tentang Keimigrasian.

\section{Internet:}

Agus Rukanda. "Imigran Gelap. http://rukandabanget.blogspot.com. Diakses tanggal 18 September 2016. Pukul 03.13 WIB

Kukuh Binanto. "Faktor Penyebab Terjadinya Suatu Tindak Kejahatan di Kota Dibandingkan di Pedesaan. http://kukuhbinanto.blogspot.com, Diakses tanggal 19 September 2016. Pukul 02.42 WIB.

Mansur Zikri. "Permasalahan Imigran Gelap dan People Smuggling dan Usahausaha serta Rekomendasi Kebijakan dalam Menanggulanginya". http:// manshurzikri.wordpress.com. Diakses tanggal 18 September 2016. Pukul $02.50 \mathrm{WIB}$.

Nugrogo. "Perlunya Kriminalisasi terhadap Kejahatan Penyeludupan Manusia di Indonesia”. https://nugrohokriminolog.blogspot.co.id. Diakses tanggal 16 Juli 2016. Pukul 01.59 WIB.

Nur Kusuma Wardani. "Trafficking pada Anak dan Perempuan”. http://journal. unair.ac.id. Diakses tanggal 18 September 2016. Pukul 03.40 WIB.

Sam Fernando. "Politik Hukum Pemerintah (Diroktorat Jendral Imigrasi) dalam Menanggulangi Masalah Penyeludupan Manusia". http:/hukum.ub.ac.id. Diakses tanggal 16 September 2016. Pukul 03.10 WIB.

Wikipedia. "Penyeludupan Manusia". http://ms.wikipedia.org. Diakses tanggal 21 Agustus 2016. Pukul 01:47 WIB. 


\section{BIODATA PENULIS}

Nama

: Mhd. Teguh Syuhada Lubis, S.H., M.H

Pekerjaan : Dosen Fakultas Hukum Universitas Muhammadiyah Sumatera Utara

Jabatan : Asisten Ahli

Nomor HP : : 081370136613

E-mail $\quad$ : teguhsuhada88@gmail.com

Alamat Kantor : J1. Kapten Muchtar Basri No. 3, Medan 